UDC 621.391

\title{
MINIMAL PLANNER MOBILE PHONE MIMO ANTENNA WITH ENHANCED GAIN
}

\author{
Vijaya Durga Ravva, Allan McLauchlin
}

Department of Electronics and Communication Engineering, University of Hertfordshire, College Ln, Hatfield AL10 9AB, UK

Background. Previously, Many MIMO designs were presented for 4G applications. Out of stated 4G MIMO antennas, few designs presented are not suitable for use in mobile phones due to their large size as compared to the standard sizes of current generation mobile phones. The rest, Ceramic based mobile phone antenna and a multi-band MIMO antenna with PIFA structures have significant heights and non-planner structure which makes them unsuitable for mobile phones as they are getting thinner with advancement in technology. Some MIMO antennas were designed with simpler structure and suitable size but they do not have adequate bandwidth. Here there is a need to develop a MIMO system with an adequate bandwidth to cover all $2 \mathrm{G}, 3 \mathrm{G}$ and $4 \mathrm{G}$ bands as well as compact to be suitable for mobile communication.

Objective. The purpose of the paper is to design a compact planner MIMO antenna Suitable for Mobile communication with enhanced gain and an enhanced bandwidth to cover all $2 \mathrm{G}, 3 \mathrm{G}$ and $4 \mathrm{G}$ bands

Methods.

i. A monopole was designed with proper dimensions, which was designed to operate at focus recurrence of $1.8 \mathrm{GHz}$. That covers the wide scope of data transfer capacity from $1.1 \mathrm{GHz}$ to $2.7 \mathrm{GHz}$ at $-9 \mathrm{~dB}$ reference line. Then an inverted $\mathrm{L}$ shape structure known as SIR stub technique is used to enhance the bandwidth.

ii. The inverted L shape structure which is extended from the ground plane is put around the monopole which generates the low resonant frequencies and also broadens the bandwidth. Bandwidth is broadened to $0.8 \mathrm{GHz}$ to $3.5 \mathrm{GHz}$.

iii. For the purpose of more impedance matching, a small patch is etched from the ground plane opposite to the feeding and all the parameters are optimized

Results. that lower $0.9 \mathrm{GHz}$ radiation pattern is omnidirectional while at higher frequencies it is quasiomnidirectional, a steady gain greater than $2.8 \mathrm{dBi}$ over the entire frequency band i.e from $.8 \mathrm{GHz}$ to $3.5 \mathrm{GHz}$, a very high gain of $6.7 \mathrm{dBi}$ at $0.9 \mathrm{GHz}$. The compact wide band planar MIMO antenna has over $80 \%$ efficiency over most of the working recurrence

For handy application ECC value less than 0.5 is adequate for mobile phones. The measured ECC is less than 0.36 over complete operating frequency band, which is all right for mobile phones

Conclusions. The paper presents compact planner two port MIMO antenna with wideband width and high gain. The proposed antenna achieved a wide bandwidth from $0.8 \mathrm{GHz}$ to $3.5 \mathrm{GHz}$ covering $2 \mathrm{G} / 3 \mathrm{G} / 4 \mathrm{G}$ bands and Wi-Fi $(2.45 \mathrm{GHz})$. High isolation between antenna elements, lower ECC and high diversity gain makes the design of the compact planner wide band MIMO antenna a suitable possibility for mobile phone applications.

Keywords: minimal; size; gain; bandwidth.

\section{INTRODUCTION}

Modern wireless technology has an increasing demand of increase data rate and high performance. Traditional wireless technologies can barely satisfy these demands. As of late, MIMO (Multiple Input Multiple Output) innovation has gained importance due to reduced multi path fading, high data capacity and high reliability [1]. Multi path fading is a big challenge in many practical applications because transmitted signals can travel from different paths to the receiver having different phase angles and amplitudes, and most probably they add up destructively at receiver. MIMO technology in antennas is the best solution to this challenge. [2]-[9] present various MIMO antennas designed specifically for certain type of communication applications. Eye catching advantages of MIMO technology have made it an important technology for $4 \mathrm{G}$ (LTE) and as 
well as for $5 \mathrm{G}$ which is a future wireless communication technology. While $2 \mathrm{G} / 3 \mathrm{G}$ technology is still in use, $4 \mathrm{G}$ communication is quickly popularizing all over the world. MIMO antennas are a perfect choice for mobile phone purposes as they offer wide bandwidth and coverage of $2 \mathrm{G} / 3 \mathrm{G} / 4 \mathrm{G}$ bands. [2]-[9] presents with a few MIMO designs for $4 \mathrm{G}$ applications. Out of stated 4G MIMO antennas, designs presented in [4]-[5] are not suitable for use in mobile phones due to their large size as compared to the standard sizes of current generation mobile phones. Ceramic based mobile phone antenna is shown in [6] and a multi-band MIMO antenna with PIFA structure is proposed in [7]. Both of them have significant heights and non-planner structure which makes them unsuitable for mobile phones as they are getting thinner with advancement in technology. MIMO antennas of [8] and [9] have simpler structure and suitable size but they do not have adequate bandwidth to cover all $2 \mathrm{G}, 3 \mathrm{G}$ and $4 \mathrm{G}$ bands. Bandwidth enhancement techniques are presented in [14-17]. The following discussion presents a planer wideband twoport MIMO antenna for smart phone application. The exhibited MIMO antenna has single element working at center frequency and an inverted L shape structure is made from ground plane to create low resonance frequencies. A two port antenna is formed by placing elements in symmetry. A slot is etched from ground plane so as to increase isolation between the individual elements. The bandwidth of the MIMO antenna under discussion ranges from $0.8 \mathrm{GHz}$ to $3.5 \mathrm{GHz}$, which covers operating bands of $2 \mathrm{G}, 3 \mathrm{G}, 4 \mathrm{G}$ and $\mathrm{Wi}-\mathrm{Fi}(2.45 \mathrm{GHz})$.

The measured and simulated isolation, peak realized gain and envelope correlation coefficient are also presented in this paper. II. GEOMETRY \& DESIGN The geometry of MIMO antenna constitutes an element located on the ground plane having dimensions of $60 \times 58 \mathrm{~mm} 2$, which is small in size as compared to the mobile phones. The substrate material used for planner MIMO antenna is FR4 with relative permittivity of 4.4 , thickness $1 \mathrm{~mm}$ and dielectric loss tangent of 0.02 . The Objective of our design is to cover a wide band which should cover $2 \mathrm{G} / 3 \mathrm{G} / 4 \mathrm{G}$ bands and Wi-Fi (2.45 GHz).

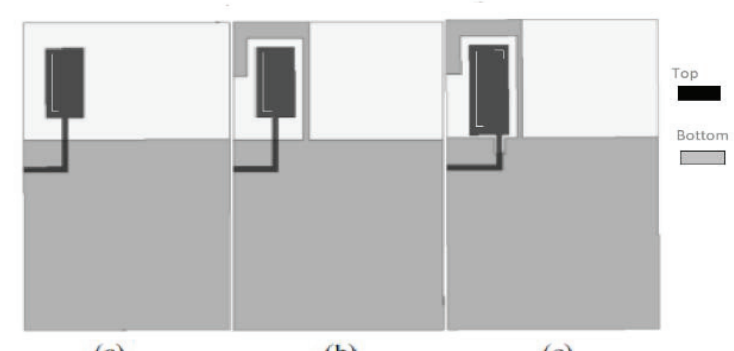

(a)

(b)

(c)

Fig. 1. Three design steps (a) Single antenna element (b) Single element with inverted L structure (c) Optimized antenna component structure

\section{A. WIDE BAND TECHNIQUE}

Fig. 1 depicts the steps for designing the planner wide band MIMO antenna. First of all, a monopole was designed with proper dimensions, which was designed to operate at focus recurrence of $1.8 \mathrm{GHz}$. A feeding strip of 50 ohms feeds the monopole. Then the design was simulated on HFSS and the simulated $\mathrm{S}$ parameters of monopole show that the monopole was covers the wide scope of data transfer capacity from $1.1 \mathrm{GHz}$ to $2.7 \mathrm{GHz}$ at $-6 \mathrm{~dB}$ reference line. Then an inverted $\mathrm{L}$ shape structure known as SIR stub technique is used to enhance the bandwidth. The inverted L shape structure which is extended from the ground plane is put around the monopole which generates the low resonant frequencies and also broadens the bandwidth. Bandwidth is broadened to $0.8 \mathrm{GHz}$ to $3.5 \mathrm{GHz}$. For the purpose of more impedance matching, a small patch is etched from the ground plane opposite to the feeding and all the parameters are optimized accordingly as appeared in Fig. 1 (b). Fig. 2 presents the $\mathrm{S}$ parameters of the optimized design of antenna element, simulated using HFSS. It can be seen that the final design is achieving $0.8 \mathrm{GHz}$ to $3.5 \mathrm{GHz}$ bandwidth with a very great impedance coordinating. 


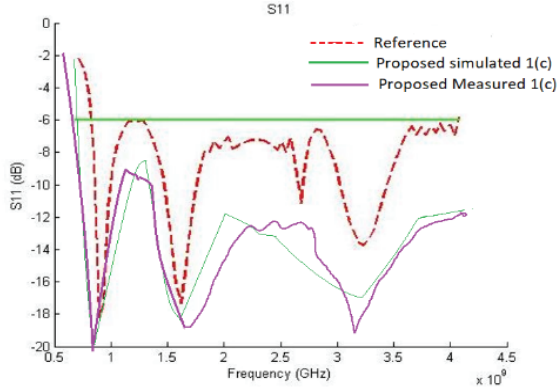

Fig. 2. Simulated $\mathrm{S}$ parameter of antenna final antenna element of 1(c)

\section{B. TWO ELEMENTS MIMO ANTENNA}

Basing on the above mentioned final design, second antenna element is introduced in the antenna design on the substrate which is totally symmetrical to form a compact wide band planar MIMO antenna as presented in Fig. 3. The compressed size of the compact wide band planar MIMO antenna is $97 \mathrm{~mm} \mathrm{X} 60 \mathrm{~mm} \mathrm{X} 1 \mathrm{~mm}$, while the size used in [9] is $125 \mathrm{~mm} 85 \mathrm{~mm} \mathrm{X}$ $0.8-\mathrm{mm}$ using FR4. The software used for the simulation is High Frequency Structured Simulation (HFSS) Version-13. The optimized parameters and dimensions of the compact wide band planar MIMO antenna are recorded in Table.1.

Table 1: Optimized Dimensions of the Antenna

\begin{tabular}{|c|c|c|c|c|c|}
\hline Parameter & $\mathbf{I 1}$ & $\mathbf{l 2}$ & $\mathbf{1 3}$ & $\mathbf{1 4}$ & $\mathbf{1 5}$ \\
\hline Value(mm) & 15 & 31.5 & 41 & 23 & 17 \\
\hline Parameter & w1 & w2 & w3 & w4 & w5 \\
\hline Value(mm) & 1 & 13 & 1.5 & 9 & 4.1 \\
\hline Parameter & Lcut & H & Hstub & Lslot & Lg \\
\hline Value(mm) & 5 & 0.1 & 0.5 & 30 & 28 \\
\hline Parameter & Wcut & Ds & Wstub & Wslot & Wg \\
\hline Value(mm) & 3 & 6.5 & 1.5 & 2 & 60 \\
\hline
\end{tabular}

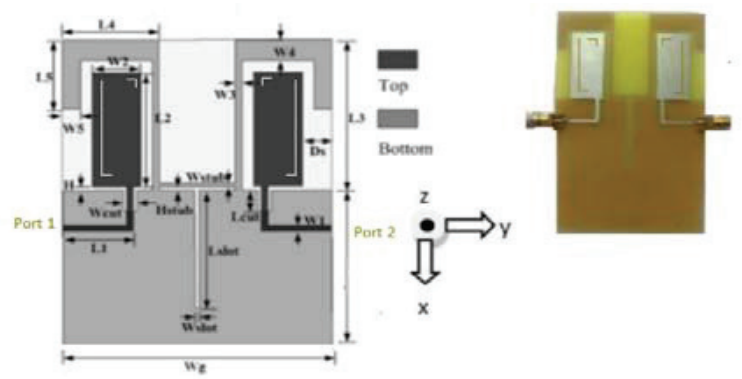

Fig. 3. Geometry of final design and prototype

Simulated and measured S parameters of the compact wide band planar MIMO antenna designs are exhibited in Fig. 4. As a result of identical geometry and positioning of the two elements, antenna achieves wider bandwidth as mentioned above. The proposed design of MIMO achieves bandwidth from $0.8 \mathrm{GHz}$ to $3.5 \mathrm{GHz}$ which covers all the bands of frequencies currently being used by major mobile phone operators across the globe.

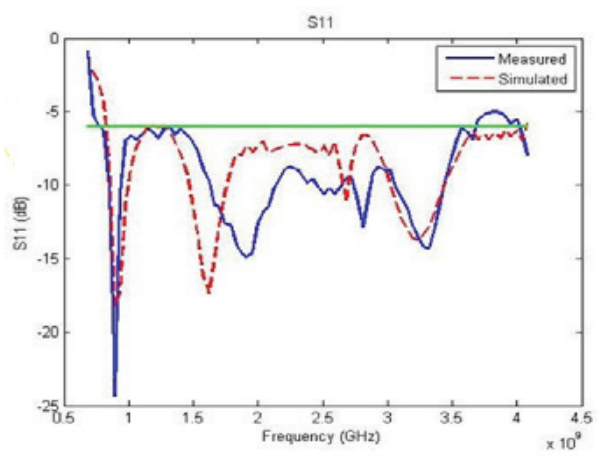

Fig. 4: Simulated and Measured S11 Table 1: Optimized Dimensions of the Antenna

\section{ISOLATION ACHIEVEMENT}

In compact wide band planar MIMO antenna design, higher isolation between antenna elements with less disturbing impedance match is one of the serious challenges. Various decoupling techniques are used in different applications [2]- [9]. In proposed design, measured isolation is achieved by drawing a slot in ground plane. It is observed that etching helps reduce isolation on lower band and on higher band it

increases isolation. Isolation can be increased by achieving a neutralization point between antenna elements as it depends mainly on the surface current flowing between them. This neutralization point depends on wavelength. In lower frequencies because of much large wavelength, the surface current and near field radiation pattern add significantly to coupling. Fig. 4 shows the simulated and measured result that $\mathrm{S} 21$ is less than $-12.5 \mathrm{~dB}$ from $0.8 \mathrm{GHz}$ to $2.1 \mathrm{GHz}$ and $-20 \mathrm{~dB}$ above $2.1 \mathrm{GHz}$ up to $3.5 \mathrm{GHz}$. III. RESULTS AND DISCUSSION Fig. 5 shows 3D plot at 0.9 GHz, $1.8 \mathrm{GHz}, 2.1 \mathrm{GHz}, 2.4 \mathrm{GHz}, 2.7 \mathrm{GHz}$ and 3.4 GHz. It shows that lower $0.9 \mathrm{GHz}$ radiation pattern is omnidirectional while at higher frequencies it is quasi-omnidirectional. Fig. 7 shows Peak realized gain; the proposed MIMO antenna has a steady gain greater than $2.8 \mathrm{dBi}$ over the entire frequency band i.e from $.8 \mathrm{GHz}$ to $3.5 \mathrm{GHz}$ of the proposed 
design and very high gain of $6.7 \mathrm{dBi}$ at $0.9 \mathrm{GHz}$. Fig. 8 shows the radiation efficiency. The compact wide band planar MIMO antenna has over $80 \%$ efficiency over most of the working recurrence band.

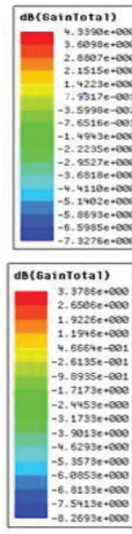

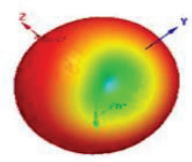

(a)

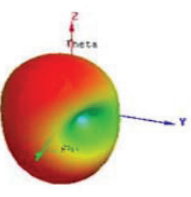

(c)

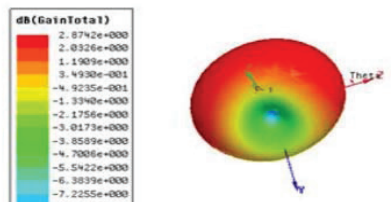

(b)

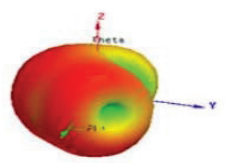

(d)
Fig. 5. 3D radiation pattern

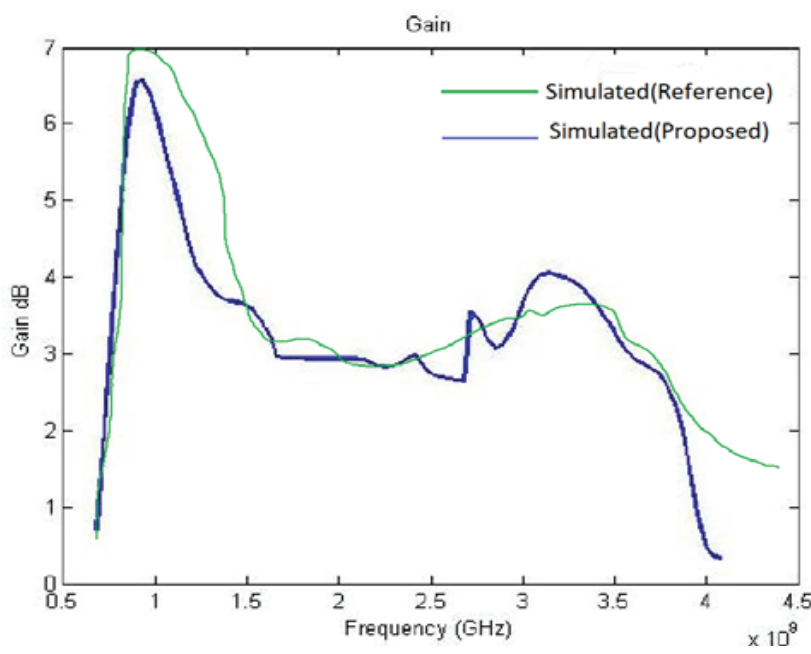

Fig. 6. Simulated Realized Peak gain

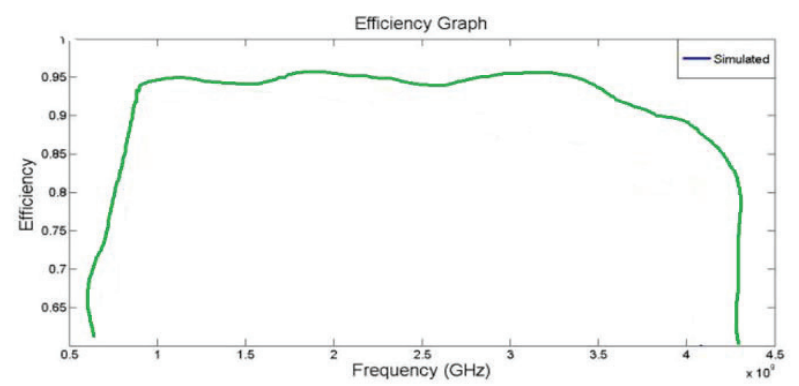

Fig. 7. Simulated Efficiency

A. Diversity Performance Efficient MIMO system is characterized by spatial diversity and channel independence. The spatial diversity and channel independence is accomplished by the reduction of the mutual coupling between antenna elements. Envelope Correlation Coefficient (ECC) is an important parameter that examines the assorted diversity execution. ECC is determined utilizing either the radiation patterns as in [10] or by using the $S$ parameters as per the method presented in [11].

$$
E C C=\left|\frac{\left|s_{12} s_{11}^{*}-s_{21} s_{22}\right|}{\left|\left(1-\left|s_{22}\right|^{2}-\left.\left|s_{12}\right|\right|^{2}\right)\left(1-\left|s_{11}\right|^{2}-\left|s_{21}\right|^{2}\right)\right|^{1 / 2}}\right|^{2}
$$

In this paper we used s-parameters to calculate ECC by using equation (1). For handi application ECC value less than 0.5 is adequate for mobile phones. Fig. 8 shows measured ECC is less than 0.36 over complete operating frequency band, which is all right for mobile phones.

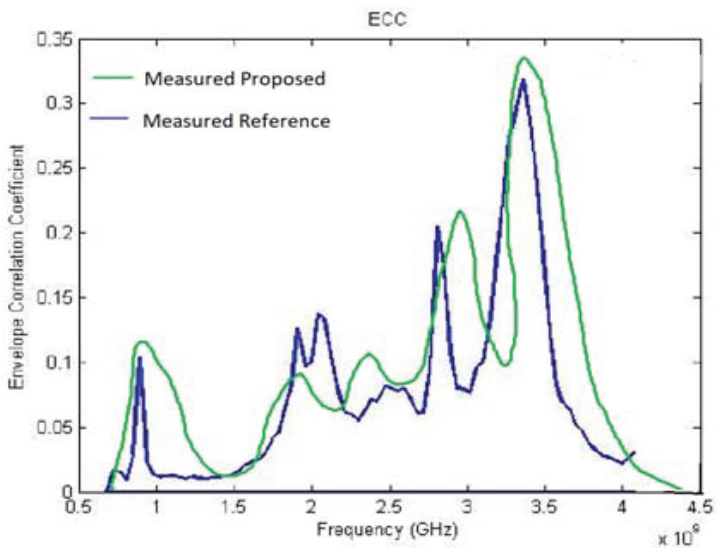

Fig. 8. Measured ECC IV.

\section{CONCLUSION}

In particular this paper compact planner two port MIMO antenna with wideband width and high gain is presented. The proposed antenna is simulated and fabricated, which achieves a wide bandwidth from $0.8 \mathrm{GHz}$ to $3.5 \mathrm{GHz}$ covering $2 \mathrm{G} / 3 \mathrm{G} / 4 \mathrm{G}$ bands and Wi-Fi $(2.45 \mathrm{GHz})$. High isolation between antenna elements, lower ECC and high diversity gain makes the design of the compact planner wide band MIMO antenna a suitable possibility for mobile phone applications.

\section{REFERENCES}

[1] M. A. Jensen, 1. W. Wallace, "A review of antennas and propagation for MIMO wireless communications," IEEE Trans. Antennas Propag., vol. 52, no. II, pp. 2810-2824, Nov. 2004. 
[2] X. Mao and Q. X. Chu, "Compact Coradiator UWB-MIMO Antenna With Dual Polarization," IEEE Trans. Antennas Propag., vol. 62, no. 9, pp. 4474-4479, Sep. 2014.

[3] W. C. Zheng, L. Zhang, Q. X. Li, and Y. Leng, "Dual-Band Dual-Polarized Compact Bowtie Antenna Array for AntiInterferenceMIMO WLAN," IEEE Trans. Antennas Propag., vol. 62, no. I, pp.237-246, Jan. 2014.

[4] S. C. Fernandez and S. K. Sharma, "Multiband Printed Meandered Loop Antennas With MIMO Implementations for Wireless Routers," IEEE Antennas Wireless Propag. Lett.,vol. 12, pp. 96-99, 2013.

[5] S. F. Roslan, M. R. Kamarudin, M.Khalily, and M. H. Jamaluddin, "An MIMO Rectangular Dielectric Resonator Antenna for 4G Applications," IEEE Antennas Wireless Propag. Lett., vol. 13, pp. 32 1-324,2014.

[6] Y. J. Ren, "Ceramic Based Small LTE MIMO Handset Antenna," IEEE Trans. Antennas Propag., vol. 61, no. 2, pp. 934-938, Feb. 2013.

[7] H. S. Singh, M. Agarwal, and G. K. Pandey, "A Quad-Band Compact Diversity Antenna for GPS L1/WiFilLTE2500/WiMAXIHIPERLANI Applications," IEEE Antennas Wireless Propag. Lett., vol. 13, pp. 249-252,2014.

[8] M. S. Sharawi, A. B. Numan, M. U. Khan, and D. N. A1oi, "A Dual-Element Dual-Band MIMO Antenna System with Enhanced Isolation for Mobile Terminals," IEEE Antennas Wireless Propag. Lett., vol. II, pp. 1006-1009,2012.

[9] S. Shoaib, I. Shoaib, N. Shoaib, X. D. Chen, and C. G. Parini, "Design and Performance Study of a Dual-Element Multiband Printed Monopole Antenna Array for MIMO Terminals," IEEE Antennas Wireless Propag. Lett., vol. 13, pp. 329-332, 2014.

[10] R. G. Vaughan and J. B. Andersen, "Antenna Diversity in Mobile Communications,"
IEEE Trans. Veh. Technol, vol. VT-36, no. 4, pp. 149-172, Nov. 1987.

[11] P. Hallbjorner, "The Significance of Radiation Efficiencies When Using S-Parameters to Calculate the Received Signal Correlation From Two Antennas," IEEE Antennas Wireless Propag. Lett.,vol. 4, pp. 97-99,2005.

[12] A.A.H. Azremi, 1. Toivanen, T. Laitinen, P. Vainikainen, X. Chen, N. Jamaly, J. Carlsson, P.$\mathrm{S}$ Kildal and S. Pivnenko, "On Diversity Performance of Two-Element Coupling Element Based Antenna Structure for Mobile Terminal," in Proc.4th. Eur. Con! Antennas Propag., 20 10, pp. 1-5.

[13] Y. Gao, X. D. Chen, Z. N. Ying and C. Parini, "Design and Performance Investigation of a Dual-Element PIFA Array at $2.5 \mathrm{GHz}$ for MIMO Terminal," IEEE Trans. Antennas Propag., vol. 55,no. 12, pp. 3433-3441, Dec. 2007.

[14] Ahmed, Z.; Perwasha, G.; Shahid, S.; Zahra, H.; Saleem, I.; Abbas, S.M.: Ultra wideband antenna with WLAN bandnotch characteristic. 2013 3rd International Conference on Computer, Control \& Communication (IC4), 1-5 (Sept. 2013).

[15] Z Ahmed, FK Lodhi, ZU Islam, F Shamshad, I Rashid, FA Bhatti, "UltraWideband Microstrip Antennas with WLAN Band-Notch Capability" International Journal of Computer and Communication System Engineering (IJCCSE), Vol. 2 (4), 2015, 575-580

[16] Z Ahmed, FK Lodhi, M Idrees, ZU Islam, FB Zarrabi, U Majeed, FA Bhatti, "A uniquelyfed miniaturized ultrawideband antenna with dual band-rejection characteristics." Sci.Int.(Lahore),27(6),5015-5019,2015.

[17] Z Ahmed, FK Lodhi, FA Bhatti, "Planar Ultra Wide Band Antennas and Band Rejection Characteristics" LAP LAMBERT Academic Publishing, 2016. 


\section{Віджая Дурга Равва, Аллан Маклоклін \\ МІМО антена 3 компактною планарною структурою 3 підвищеним посиленням для мобільного телефону}

Проблематика. Раніше було представлено багато проектів MIMO для технологій 4G. Iз заявлених 4G MIMO-антен деякі представлені конструкції не підходять для використання в мобільних телефонах через їх великі розміри в порівнянні зі стандартними розмірами мобільних телефонів поточного покоління. Інші рішення, засновані на керамічних антенах для мобільного телефону і багатодіапазонними антени МIMO зі структурами PIFA, мають значну висоту і не планарну структуру, що робить їх непридатними для мобільних телефонів, оскільки ті стають все тонше з розвитком технологій. Деякі антени МІМО були розроблені з більш простою структурою і відповідним розміром, але вони не мають достатньої смуги пропускання. Пропонується розробити систему $\mathrm{MIMO} з$ достатньою шириною смуги, щоб охопити всі діапазони $2 \mathrm{G}, 3 \mathrm{G}$ i 4G, а також компактні габарити, щоб вона підходила для мобільного зв'язку.

Мета дослідження. Розробка компактної планарної антени МIMO, що підходить для мобільного зв'язку з поліпшеним посиленням і розширеною смугою пропускання, щоб охопити всі діапазони 2G, 3G i 4G.

Методика реалізації.

I. Монополь був спроектований з належними розмірами, розроблений для роботи при частоті фокусування 1,8 ГГц при охопленні широкого спектру потужності передачі даних від 1,1 ГГц до 2,7 ГГц при -9 дБ контрольної лінії. Далі використовується інвертована структура L-форми, відома як метод заглушки SIR, для збільшення смуги пропускання.

II. Інвертована L-образна структура, яка витягнута в площині, розташована навколо монополя, який генерує низькі резонансні частоти, а також розширює смугу пропускання. Смуга пропускання розширена від 0,8 ГГц до 3,5 ГГц.

III. 3 метою більш повного узгодження імпедансів, протравлено невелику накладку в напрямку, протилежному подачі живлення, і всі параметри оптимізовані.

Результати дослідження. На частотах нижче 0,9 ГГц діаграма спрямованості є ненаправленої, в той час як на більш високих частотах вона квазі-ненаправлена, постійне посилення понад 2,8 дБі у всій смузі частот, тобто від 0,8 ГГц до 3,5 ГГц, дуже високе посилення 6,7 дБі при 0,9 ГГц. Компактна плоска широкосмугова антена МIMO має ККД більше $80 \%$ протягом більшої частини робочих циклів.

Для зручного застосування значення коефіцієнта кореляції за огинаючою сигналу (ККО) менше ніж 0,5 підходить для мобільних телефонів. Виміряне значення ККО становить менше 0,36 в повній робочій смузі частот, що добре для мобільних телефонів.

Висновки. У цій статті представлено компактна планарна структура двухпортовой антени МІМО 3 широкою смугою i високим коефіцієнтом посилення. Запропонована антена досягла широкої смуги пропускання від 0,8 ГГц до 3,5 ГГц, що охоплює діапазони 2G / 3G / 4G i Wi-Fi (2,45 ГГц). Висока ізоляція між антенними елементами, більш низьке значення ККО і високий коефіцієнт рознесення роблять конструкцію широкосмугового антени МIMO компактної планарної структури підходящої для використання в мобільних телефонах.

Ключові слова: антена МIMO; мінімальний розмір; підвищене посилення; адекватна пропускна здатність.

\section{Виджая Дурга Равва, Аллан МакЛоклин}

МІМО антенна с компактной планарной структурой с повышенным усилением для мобильного телефона

Проблематика. Ранее были представлены многие проекты MIMO для приложений 4G. Из заявленных 4G МIMО-антенн некоторые представленные конструкции не подходят для использования в мобильных телефонах из-за их большого размера по сравнению со стандартными размерами мобильных телефонов текущего поколения. Другие решения, основанные на керамических антеннах для мобильного телефона и многодиапазонной антенне MIMO со структурами PIFA, имеют значительную высоту и не планарную структуру, что делает их непригодными для мобильных телефонов, поскольку те становятся все тоньше с развитием технологий. Некоторые антенны MIMO были разработаны с более простой структурой и подходящим размером, но они не имеют достаточной полосы пропускания. Предлагается разработать 
систему MIMO с достаточной шириной полосы, чтобы охватить все диапазоны $2 \mathrm{G}$, $3 \mathrm{G}$ и $4 \mathrm{G}$, а также компактными габаритами, чтобы она подходила для мобильной связи.

Цель исследования. Разработка компактной планарной антенны MIMO, подходящей для мобильной связи с улучшенным усилением и расширенной полосой пропускания, чтобы охватить все диапазоны $2 \mathrm{G}, 3 \mathrm{G}$ и $4 \mathrm{G}$.

Методика реализации.

I. Монополь был спроектирован с надлежащими размерами, разработан для работы при частоте фокусировки 1,8 ГГц при охвате широкого спектра мощности передачи данных от 1,1 ГГц до 2,7 ГГц при -9 дБ контрольной линии. Далее используется инвертированная структура L-формы, известная как метод заглушки SIR, для увеличения полосы пропускания.

II. Инвертированная L-образная структура, которая вытянута в плоскости, расположена вокруг монополя, который генерирует низкие резонансные частоты, а также расширяет полосу пропускания. Полоса пропускания расширена от 0,8 ГГц до 3,5 ГГц.

III. В целях более полного согласования импедансов, протравлена небольшая накладка в направлении, противоположном подаче питания, и все параметры оптимизированы.

Результаты исследования. На частотах ниже 0,9 ГГц диаграмма направленности является ненаправленной, в то время как на более высоких частотах она квази-ненаправленная, постоянное усиление более 2,8 дБи во всей полосе частот, то есть от 0,8 ГГц до 3,5 ГГц, очень высокое усиление 6,7 дБи при 0,9 ГГц. Компактная плоская широкополосная антенна МIMO имеет КПД более $80 \%$ в течение большей части рабочих циклов.

Для удобного применения значение коэффициента корреляции по огибающей сигнала (ККО) меньше чем 0,5 подходит для мобильных телефонов. Измеренное значение ККО составляет менее 0,36 в полной рабочей полосе частот, что хорошо для мобильных телефонов.

Выводы. В этой статье представлена компактная планарная структура двухпортовой антенны МIMO с широкой полосой и высоким коэффициентом усиления. Предложенная антенна достигла широкой полосы пропускания от 0,8 ГГц до 3,5 ГГц, охватывающей диапазоны 2G / 3G / 4G и Wi-Fi (2,45 ГГц). Высокая изоляция между антенными элементами, более низкое значение ККО и высокий коэффициент разнесения делают конструкцию широкополосной антенны МIMO компактной планарной структуры, подходящей для приложений в мобильных телефонах.

Ключевые слова: антенна MIMO; минимальный размер; повышенное усиление; адекватная пропускная способность. 